\title{
THE HEATS OF COMBUSTION OF ALUMINIUM, CALCIUM, AND MAGNESIUM,
}

\author{
By F. E. WESTON, B.Sc., and H. R. ELLIS, B.Sc.
}

(A Paper read before the Faraday Society on Tuesday, December 15, Igo8, Dr. T. M. LOWRY in the Chair.)

The values given by various experimenters for the heats of formation of $\mathrm{Al}_{2} \mathrm{O}_{3}, \mathrm{CaO}$, and $\mathrm{MgO}$ differ very considerably, as is shown in the following table :-

I. $\mathrm{Mg}+\mathrm{O}=\mathrm{MgO}-$ Heat Evolution. I 48,000 calories $\quad \ldots \quad$ Dr. Strauss, Minet, Production of $A l$, p. 209.

I $43,300 \quad, \quad \ldots$ Beketoff.

I 43,400 $\quad \ldots \quad$ Electrochemical and Metallurgical Industry, 6-8.

II. $\mathrm{Ca}+\mathrm{O}=\mathrm{CaO}-$

I51,900 calories ... A. Guntz and H. Bassett, jun., C. R., ז905, 140, 863,864 .

I3I,500 " $\quad \ldots$ Thomsen (see L, and B.).

I $45,000 \quad " \quad \ldots$ Moissan.

I31,648 " $\quad$.. Dr. Strauss, Minet, Production of Al, p. 209.

I30,900 " $"$... Thomsen,

Guntz used pure $\mathrm{Ca}$ and formed pure compounds, from which he determined the heats of solution ; this, of course, introduces complications, leading to various corrections. Forcrand, using pure $\mathrm{CaO}$ from $\mathrm{Ca}(\mathrm{OH})_{2}$ and determining heats of solution, obtained the same value as Guntz (C. R., I908, 146, 2I7-220). Thomsen used $\mathrm{CaO}$ prepared from calcium nitrate, and Forcrand (C. $R$., $146,217-220$ ) points out that the low value obtained was probably due to impurities; consequently all values based on Thomsen's results will be low (see also F. C. S., Abst. II., I55, 1908).

Moissan's result was obtained by direct determination of the heat of combustion, and therefore is less liable to error than those results obtained by indirect means.

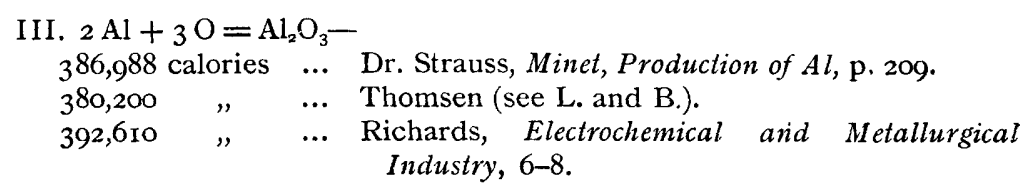

Calculating these results for I gram-atom of $O$, they become 128,996 , I26,733, and 130,870 respectively.

On account of the great divergence in the above numbers, experiments were carried out with a view of ascertaining as far as possible which element has the greatest heat of combustion by examining the reducibility of the oxides of aluminium, calcium, and magnesium by the metals $\mathrm{Al}, \mathrm{Ca}$, and $\mathrm{Mg}$ respectively. 
From the foregoing tables it will be seen that the average value of the heat of combustion of $\mathrm{Mg}$ is 145,000 calories, that of $\mathrm{Ca}$ is 137,000 calories, and that of $\mathrm{Al}$ is $\mathrm{I29}, 000$ calories; hence from the theory of greatest heat development $\mathrm{Mg}$ should reduce $\mathrm{CaO}$ and $\mathrm{Al}_{2} \mathrm{O}_{3}, \mathrm{Ca}$ should reduce $\mathrm{Al}_{2} \mathrm{O}_{3}$ and not $\mathrm{MgO}$, and $\mathrm{Al}$ should not reduce $\mathrm{CaO}$ or $\mathrm{MgO}$.

Now Goldschmidt (Minet, Production of Al, p. 213) has already shown that $\mathrm{Al}$ can reduce $\mathrm{CaO}$, and Dr. F. M. Perkin has succeeded in reducing $\mathrm{Al}_{2} \mathrm{O}_{3}$ by $\mathrm{Ca}$; but it was thought advisable to repeat these experiments in order that a complete comparison could be made between the various reductions when carried out under the same conditions.

\section{EXPERIMENTAL.}

Series I. The Action of Al Powder upon $\mathrm{Al}_{2} \mathrm{O}_{3}, \mathrm{MgO}$, and $\mathrm{CaO}$ respectively.

The Al powder was the same as that used by the authors in their previous work (see Trans. Far. Soc., vol. iv., 1, I908). The $\mathrm{Al}_{2} \mathrm{O}_{3}$ was prepared by ignition of pure ammonia alum. The MgO was made by ignition of precipitated magnesium carbonate, and was heated for some hours in a muffle at $\mathrm{r}, 000^{\circ} \mathrm{C}$. and was in an extremely fine state of division. The $\mathrm{CaO}$ was obtained by ignition of marble, finely powdered, passed through a 40,000 meshed sieve, and the resulting powder again heated at $\mathrm{i}, 000^{\circ} \mathrm{C}$. for one hour.

I. $\mathrm{Al}_{2} \mathrm{O}_{3}+4 \mathrm{Al}$. This experiment was first carried out by Duboin (C.R., cxxxii., No. 13). The mixture readily reacts with a fuse, forming a blackishgrey product which dissolves in $\mathrm{HCl}$ with the evolution of $\mathrm{H}$; it contains, probably, a suboxide of aluminium, but very little nitride.

2. $2 \mathrm{Al}+3 \mathrm{CaO}$. The mixture, contained in a Hessian crucible, would not react in the cold, even when a fairly large fuse was used; when heated over a bunsen burner for two hours (the bottom of the crucible was at a dull red heat), a fuse again brought about no reaction. The crucible was then placed in the muffle at its hottest part; after two minutes, the crucible then being bright red, action started at the surface and then very rapidly spread throughout the whole mass, giving a somewhat violent reaction. The reaction consisted first of the oxidation of the surface Al by the air, and the heat produced by this reaction, together with the heat supplied by the furnace, brought about the reduction of the $\mathrm{CaO}$ by the $\mathrm{Al}$; this reaction appears to us to be endothermic, since it was only possible to bring about the reaction under the conditions stated. The product of the reaction consisted of a hard, black, fused mass, and contained free $\mathrm{Ca}$, calcium aluminate, free $\mathrm{Al}$ (and possibly some $\mathrm{Al}_{2} \mathrm{O}$ ), $\mathrm{Al}_{2} \mathrm{O}_{3}$, and $\mathrm{CaO}$; it also contained a small amount of nitride and carbide.

Estimation of Free $\mathrm{Ca}$ and $\mathrm{Al}$.- The finely powdered substance was treated with cold water and the gas evolved collected and analysed. From volume of $\mathrm{H}$ evolved the percentage of free Ca was calculated; a small quantity of $\mathrm{C}_{2} \mathrm{H}_{2}$ and $\mathrm{CH}_{4}$ was found present. After treatment with water, $\mathrm{HCl}$ was added and the process repeated.

$$
\begin{gathered}
\text { Per cent. free } \mathrm{Ca}=8 \cdot 3 \\
" \quad, \quad \text { free } \mathrm{Al}=6 \cdot \mathrm{I} \\
" \quad, \quad \text { nitrogen }=0.375 \\
\quad \text { (as nitride) }
\end{gathered}
$$

Hence it is evident that $\mathrm{Al}$ powder can reduce $\mathrm{CaO}$ at high temperatures, and it is probable that the reaction $2 \mathrm{Al}+3 \mathrm{CaO} \rightleftarrows 3 \mathrm{Ca}+\mathrm{Al}_{2} \mathrm{O}_{3}$ is a reversible one and that a stage of equilibrium is reached under the above conditions. 


\section{I68 THE HEATS OF COMBUSTION OF ALUMINIUM,}

3. $2 \mathrm{Al}+3 \mathrm{MgO}$. The reduction could not be brought about even at the highest temperature attainable $\left(e . g\right.$., about $\mathrm{I}, 100^{\circ} \mathrm{C}$.) ; the only change obtained was a superficial oxidation of the $\mathrm{Al}$; the contents of the crucible were otherwise unacted upon.

Hence it appears that the heat of formation of $\mathrm{MgO}$ is greater than that of $\mathrm{CaO}$.

\section{Series $I I$.}

I. $3 \mathrm{Ca}+\mathrm{Al}_{2} \mathrm{O}_{3}$. The calcium was first converted into fine shavings in a lathe, and these were then crushed as small as possible in an iron mortar, and that portion which passed through a I20-meshed sieve was used.

The mixture, in a Hessian crucible, would not react in the cold even when a moderately large fuse was used, but on heating with a bunsen burner until the bottom of the crucible was at a dull red heat, a violent reaction took place and the larger portion of the contents of the crucible was ejected. From the way in which the reaction took place it is fair to assume that if calcium powder in a sufficiently fine state of division were employed the reduction would take place readily in the cold, and if air were excluded and sufficiently large quantities of mixture employed, fused Al could be obtained (see also Dr. Perkin, T. F. S., iii., 3, 184 ). In this reaction the Al produced probably volatilised, and consequently oxidised under the very high temperature obtained, and this may account for the small percentage of $\mathrm{Al}$ found and also for Dr. Perkin's failure to obtain globules of metallic Al. The authors intend repeating this experiment under such conditions as to avoid loss, \&c.

The presence of free $\mathrm{Al}$ was shown by treating the finely powdered product with water until no more gas was evolved, even on heating, and then adding $\mathrm{HCl}$; a rapid effervescence of $\mathrm{H}$ took place, and $\mathrm{Al}$ was found in the solution. The product contained about 8 per cent. of free Al.

2. Ca $+\mathrm{MgO}$. The mixture, placed in a Hessian crucible, was found to react slowly when the surface was heated with a bunsen burner; the surface $\mathrm{Ca}$ ignited, and the incandescence slowly spread throughout the mass from the top downwards. On cooling the contents of the crucible were found to be white at the top to a depth of about $\frac{1}{8}$ inch, and then of a deep yellow.

It was thought at first the action was due to reaction of the $\mathrm{Ca}$ with the atmosphere forming a small amount of lime and a large amount of calcium nitride. That this was not so was evident from ( $\mathrm{r}$ ) the analysis of the resulting mixture; (2) that the calcium when heated in a crucible by itself under the same conditions only burnt on the surface and remained unchanged below; and (3) a mixture of $\mathrm{CaO}$ and $\mathrm{Ca}$ when treated in the same manner or even when strongly heated by a Bunsen flame only reacted at the surface.

Analysis of the product gave-

$$
\begin{aligned}
\mathrm{N} \text { as nitride } & =5.79 \text { per cent. } \\
\text { Free } \mathrm{Ca} & =4.16, ", \\
, \quad \mathrm{Mg} & =0.58,, \quad,
\end{aligned}
$$

It was not possible to decide whether the nitride was calcium nitride or magnesium nitride or a mixture of both. But from the large percentage of nitride (about 30 per cent. if calcium nitride) it appears that the atmospheric $\mathrm{N}$ plays a great part in the reaction observed.

\section{Series III.}

I. $\mathrm{Mg}+\mathrm{CaO}$. That $\mathrm{Mg}$ will readily reduce $\mathrm{CaO}$ in the cold is, of course well known, this reaction serving for the preparation of argon from the air. A mixture made in the proportion $\mathrm{Mg}+\mathrm{CaO}$ can easily be fired by a lighted 
match, the reaction proceeding steadily throughout the mass. The resulting product is of a bright yellow colour, and consists chiefly of calcium nitride.

Analysis of product gave-

$$
\begin{aligned}
\mathrm{Ca}_{3} \mathrm{~N}_{2} & =33.65 \text { per cent. } \\
\text { Free } \mathrm{Ca} & =1.29, ", \\
, \mathrm{Mg} & =0^{*} 47, ",
\end{aligned}
$$

In this reaction, in order to obtain a yield of $\mathrm{Ca}$, air would have to be excluded.

2. $3 \mathrm{Mg}+\mathrm{Al}_{2} \mathrm{O}_{3}$. This mixture, in a Hessian crucible, easily reacted with a fuse ; the reaction was somewhat violent, the mass swelling up considerably. The resulting product was quite black.

Analysis of product gave-

$$
\begin{aligned}
\mathrm{N} \text { as nitride } & =7.43 \text { per cent. } \\
\text { Free } \mathrm{Al} & =0.7 \mathrm{I} \quad, \quad, \\
, \mathrm{Mg} & =3.87, ",
\end{aligned}
$$

In this reaction, as in the case of $\mathrm{Ca}$ and $\mathrm{Al}_{2} \mathrm{O}_{3}$, it is probable that most of the $\mathrm{Al}$ liberated is converted into nitride and some re-oxidised to $\mathrm{Al}_{2} \mathrm{O}_{3}$.

Although in these experiments, which were only carried out on a small scale (20 to 50 grams), complications arise partly from the interaction of the various hot metals with the air and with the oxides, it is quite evident that both $\mathrm{Mg}$ and $\mathrm{Ca}$ reduce $\mathrm{Al}_{2} \mathrm{O}_{3}$ in the cold and also that $\mathrm{Mg}$ easily reduces $\mathrm{CaO}$ with the formation of the free metal.

It is thus evident that the heat of combustion of $\mathrm{Mg}$ is greater than that of $\mathrm{Ca}$, since $\mathrm{MgO}$ is not reduced by $\mathrm{Al}$, whilst $\mathrm{CaO}$ is at a very high temperature ; however, the heat of combustion of $\mathrm{Mg}$ is not much greater than that of $\mathrm{Ca}$, since it is possible to cause $\mathrm{Ca}$ to interact with $\mathrm{MgO}$; also the heats of combustion of $\mathrm{Mg}$ and $\mathrm{Ca}$ are much higher than that of $\mathrm{Al}$.

The partial reductions of $\mathrm{CaO}$ by $\mathrm{Al}$ and of $\mathrm{MgO}$ by $\mathrm{Ca}-$ probably endothermic reactions-are analogous to the reduction of $\mathrm{B}_{2} \mathrm{O}_{3}$ by $\mathrm{K}$ and $\mathrm{Na}$ respectively. Gay-Lussac prepared $\mathrm{B}$ by heating $\mathrm{B}_{2} \mathrm{O}_{3}$ with $\mathrm{K}$ to a red heat in an iron tube. Now, the heat of combustion of $\mathrm{B}$ to $\mathrm{B}_{2} \mathrm{O}_{3}$ is given as 3I7,200 (Troost and Hautefeuille-Watts, Dictionary), 3I4,82I by Roscoe and Schorlemner; whilst the heat of combustion of $\mathrm{K}$ to $\mathrm{K}_{2} \mathrm{O}$ is given by Beketoff as $97, \mathbf{1 0 0}$ (L. and B.), 86,800 by Rengarde (F. C. S., Abs. II., 156, 1908), and 84,800 (ibid.).

Hence $\mathrm{B}_{2} \mathrm{O}_{3}+6 \mathrm{~K}=3 \mathrm{~K}_{2} \mathrm{O}+\mathrm{B}_{2}$ becomes thermally (using average values)

$$
i . e .=-47,500 ;
$$

i.e., heat must be supplied; a similar reaction occurs with $\mathrm{Na}$.

Chemical Laboratory,

The Polytechnic,

Regent Street, W. 